\title{
Toxicity Assessment and Evaluation of Analgesic, Antipyretic and Anti-Inflammatory Activities on Cordia obliqua Leaf Methanol Extract
}

\author{
Richa Gupta', Ghanshyam Das Gupta ${ }^{2 *}$
}

\section{Richa Gupta ${ }^{1}$, Ghanshyam Das Gupta ${ }^{2 *}$ \\ 'PhD scholar of IKG Punjab Technical University Jallandhar and Assistant Pro- fessor, Department of Pharmacognosy, ASBASJSM College of Pharmacy, Bela (Ropar), 140111, Punjab, INDIA. ${ }^{2}$ Department of Pharmaceutics, ISF College of Pharmacy, Ghal Kalan, Ferozpur G. T. Road, Moga, 142001, Punjab, INDIA.}

Correspondence

Dr. Ghanshyam Das Gupta

Director, Department of Pharmaceutics, ISF College of Pharmacy, Ghal Kalan, Ferozpur G. T. Road, Moga, 142001, Punjab, INDIA.

Phone no: +91-8146562883

E-mail: drgdgp@gmail.com

History

- Submission Date: 08-06-2017;

- Review completed: 28-07-2017;

- Accepted Date: 22-08-2017.

DOI : 10.5530/pj.2017.6.134

Article Available online

http://www.phcogj.com/v9/i6

Copyright

(C) 2017 Phcog.Net. This is an openaccess article distributed under the terms of the Creative Commons Attribution 4.0 International license.

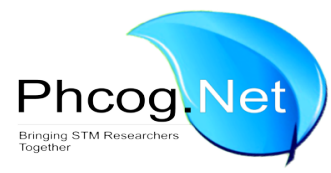

\begin{abstract}
Background: Cordia obliqua Willd. Plant belongs to genus Cordia and family Boraginaceae. Commonly it is known as Clammy Cherry and in Hindi Lasora. Earlier very few researches were carried out to explore its medicinal importance as compared with other Cordia species. Objective: To determine maximum safe dose and explore analgesic, anti-inflammatory and antipyretic activities of Cordia obliqua leaf methanol extract. Materials and Methods: As per our previous study report, the leaf methanol extract is rich in phyto-constituents and has good antioxidant effect; so only methanol extract was studied here. The maximum safe dose of methanol extract was found by acute oral toxicity study according to OECD guidelines 423. For analgesic effect, hot plate and tail flick method, for anti-inflammatory, Carageenan induced rat paw edema and for antipyretic study, yeast induced pyrexia method were used. Results: The extract dose up to $2000 \mathrm{mg} / \mathrm{Kg}$ was found safe with no any side effects. Three dose levels were tested for all activities. The medium $(250 \mathrm{mg} / \mathrm{Kg})$ and high $(500 \mathrm{mg} / \mathrm{Kg})$ dose of methanol extract was found effective in all activities when compared with standard. The result for antipyretic activity was found better than other activities. Conclusion: It can be concluded that Cordia obliqua leaf is safe and effective drug for relief of pain, fever and inflammation.
\end{abstract}

Key words: Carageenan induced edema, Clammy Cherry, Hot plate, Tail flick, Yeast induced pyrexia.

\section{INTRODUCTION}

Higher plants are a rich source of various secondary metabolites with a number of important medicinal activities. So, plants have been used by human being in traditional medicine since ages due to their therapeutic potential. ${ }^{1}$ Cordia obliqua Willd. is a well-known plant of Boraginaceae family and Cordia genus? It is found scattered throughout mid-Himalayas up to an elevation of 1,470 meters. It is a deciduous tree with medium size (height 10.5 meters) and vigorous growth. It is commonly known as Clammy Cherry and in Hindi, called as Lasora. ${ }^{2}$ Traditionally, the plant is used as anthelmintic, expectorant, purgative, diuretic and in treatment of chronic fever, dry cough, joints pain, spleen diseases and burning of throat. The leaves are useful in treatment of headache and ulcer. Its fruits are sweet and used in raw form as vegetable and pickle. Scientifically, this plant is used as hypotensive, respiratory stimulant, diuretic, anti-inflammatory and antimicrobial. $^{3}$

Till this work done, no any activity of C. obliqua leaves is reported except antimicrobial. So, this research work was carried out to explore the pharmacological importance and determine the chemical nature of leaves. For this methanol extract of leaves was selected because as our previous study, methanol extract is rich in various Phyto-constituents and has good antioxidant effect. ${ }^{4}$

At first, acute oral toxicity study was performed to determine maximum safe dose of leaf methanol extract and then various activities like analgesic (by Hot plate and Tail flick method), anti-inflammatory (by Carageenan induced rat paw edema method) and antipyretic (by yeast induced pyrexia method) were performed.

\section{MATERIALS AND METHODS}

\section{Plant material}

The Cordia obliqua Willd. leaves were procured from Jammu. These were authenticated and identified by Dr. (Mrs) Sunita Garg, Chief Scientist, Raw Material Herbarium and Museum (RHMD), Council of Scientific and Industrial Research-National Institute of Science and Information Resources (CSIR-NISCAIR), New Delhi, with the reference no. NISCAIR/RHMD/Consult/-2014/2383-163. A plant sample was deposited in herbarium of Phar-

Cite this article: Gupta R, Gupta GD. Toxicity Assessment and Evaluation of Analgesic, Antipyretic and Anti-Inflammatory Activities on Cordia obliqua Leaf Methanol Extract. Pharmacog J. 2017;9(6):856-61. 
macognosy department, ASBASJSM College of pharmacy, Bela (Ropar) for future reference.

\section{Extraction method}

About $1 \mathrm{Kg}$ of leaf drug was dried under shade and then coarsely powdered. The successive extraction was performed using soxhlet apparatus with a number of solvents such as Hexane, Chloroform, Methanol and water in order of increasing polarity. All the four extracts were separately concentrated using Rotary vacuum evaporator and then kept in desiccator for further use. The yield of methanol extract was found $1.2 \% \mathrm{w} / \mathrm{w}$ and it was dark Green in color and non-sticky. As per the previous study, methanol extract contains maximum number of Phyto-constituents as well as maximum total phenol and total flavonoid content. So, leaf methanol extract was selected for biological activity study.

\section{Animals}

The Albino rats of the body weight range 180-200g were used for the present study. The rats were maintained under standard conditions of environment and feed with standard pellet diet. Before starting of experiment, the animals were given time of seven days to get acclimatized with laboratory environment conditions. The animals were fasted for $18 \mathrm{hrs}$ before the experiment. After sufficient period of acclimatization, they were used to evaluate anti-inflammatory, anti- pyretic and analgesic activities. The experimental protocol was subjected to the scrutinization of IAEC of ASBASJSM College of Pharmacy, Bela and was duly approved under the Protocol No. ASCB/IAEC/07/14/92 and care of animals were carried out according to the guidelines of CPCSEA, New Delhi (Regn. No. 724/PO/a/02/CPCSEA).

\section{Chemicals and drugs}

Indomethacin (Glenmark Generics Ltd, Goa), Paracetamol (Yarrow Chem, Mumbai) and Carageenan (Himedia, Mumbai) were used for present study.

\section{Acute Toxicity Study}

The acute toxicity for the methanol extract dose was determined in albino rats by adopting Acute Toxic Dose method of CPCSEA (OECD guidelines No. 423). Animals were weighed and divided in four groups of three animals in each. They were administered group wise increasing dose of extract like 5, 50, 300 and $2000 \mathrm{mg} / \mathrm{kg}$ Body Weight (BW) to determine changes in parameters for assessing toxicity. The animals were maintained under standard environmental conditions and allowed free access to water and food. These were observed continuously after drug administration at regular time interval on first day to fourteen consecutive days for behaviour profile, neurological profile and autonomic profile. ${ }^{5}$

\section{Analgesic activity}

The analgesic activity of leaf methanol extract was determined by using two methods- (1) Tail Flick method or Tail immersion method based on thermal radiant heat as a pain source; (2) Hot plate method based on jumping of animal or withdrawal of paws from hot plate at $55^{\circ} \mathrm{C}$. These both methods determine central analgesic effect of drug. ${ }^{6}$

In both methods, Animals were divided in five groups of six animals in each, one control group, one standard group and three groups for three dose levels of leaf methanol extract- low dose (125mg/kg BW), Medium dose $(250 \mathrm{mg} / \mathrm{kg} \mathrm{BW})$ and high dose $(500 \mathrm{mg} / \mathrm{Kg} \mathrm{BW})$ per oral.

\section{Tail Flick method}

The animals received vehicle Normal saline 10ml/kg BW (Group I) and standard drug Indomethacin $10 \mathrm{mg} / \mathrm{kg}$ BW per oral (Group II). Analgesic activity at three doses of leaf methanol extract (Group III, IV, V respectively) was assessed by observing the reaction time in the treated groups. Reaction time in seconds was used as the unit for measurement of pain and analgesic effect was indicated by increase in reaction time. Time between placing the tail of the rat on the radiant heat source and sharp withdrawal of the tail was recorded as "reaction time". While noting down the reaction time, cut off time of ten sec was used in all experiments as maximum latency to rule out thermal injury. Animals were discarded that has showed a mean reaction time outside the range of five-six sec. In all the groups, tail-flick test was performed prior to drug administration, and at $0,30,60,90$ and $120 \mathrm{~min}$ after drug administration, and the reaction time at each time interval was calculated. ${ }^{7,8}$

\section{Hot plate method}

The animals were acclimatized of laboratory conditions $1 \mathrm{~h}$ before the start of experiment. Animals were then subjected to pre-testing on hot plate apparatus maintained at $55 \pm 0.1^{\circ} \mathrm{C}$. During pre-testing, the animals were rejected showing latency time more than $15 \mathrm{sec}$. Then animals were divided in five groups of six animals in each. The group I was control group and treated with Normal saline $(10 \mathrm{ml} / \mathrm{kg}$ BW), Group II was treated with standard drug Indomethacin $(10 \mathrm{mg} / \mathrm{kg} \mathrm{BW})$ and group III, IV and $\mathrm{V}$ were treated with three dose level of leaf methanol extract. At first, the latency time in sec was noted after $30 \mathrm{~min}$ of treatment .by placing the animals on Hot plate. In order to prevent the tissue damage, a cut-off time of $15 \mathrm{sec}$ was used for all animals. The latency time was recorded for all animals at $0,30,60,90$ and 120 min..$^{9-11}$

\section{Antipyretic activity}

The antipyretic activity was determined by using Yeast induced Pyrexia method using Paracetamol as standard drug.

\section{Yeast induced Pyrexia method}

Animals were divided into five groups of six animals in each group. The initial rectal temperature of each animal was recorded by insertion of digital thermometer to a depth of $2 \mathrm{~cm}$ into the rectum. The pyrexia was induced by injecting a suspension of $15 \%$ of brewer's yeast in normal saline, sub-cutaneously in the volume of $1 \mathrm{ml} / 100 \mathrm{~g}$ of animal weight. The site of injection was massaged to spread the suspension beneath the skin. The room temperature was kept at $22-24^{\circ} \mathrm{C}$. Immediately after yeast administration, food was withdrawn. A stabilized temperature was produce in $18 \mathrm{~h}$. and recorded. The measurement was repeated after $30 \mathrm{~min}$. Only animals with a body temperature of at least $38^{\circ} \mathrm{C}$ were taken into the test. Group 1 as control, received $10 \mathrm{ml} / \mathrm{kg}$ of normal saline solution orally. The group II was administered with Paracetamol orally at dose of $100 \mathrm{mg} / \mathrm{kg}$ BW. The III, IV and V group received three doses of methanol extract $125 \mathrm{mg} / \mathrm{kg}, 250 \mathrm{mg} / \mathrm{kg}$ and $500 \mathrm{mg} / \mathrm{kg}$ BW respectively. The test drug was given orally $(0 \mathrm{~h})$ and rectal temperature recorded at 1, 2, 3 and $4 \mathrm{~h}$. The difference in temperature between $0 \mathrm{~h}$ and at the end of $4 \mathrm{~h}$ was compared and analysed..$^{8-12}$

\section{Anti-inflammatory activity}

It was determined by Carageenan-induced rat paw edema method using Indomethacin as standard drug.

\section{Carrageenan-induced rat paw edema}

Albino Wister Rats were allotted to a total of six groups as Negative control, Positive control, standard treatment group and three groups for low, medium and high dose of leaf methanol extract $125 \mathrm{mg} / \mathrm{kg}$, $250 \mathrm{mg} / \mathrm{kg}$ and $500 \mathrm{mg} / \mathrm{kg}$ BW respectively. Edema was induced in the rats by injection of Carrageenan $(0.1 \mathrm{ml}, 1 \% \mathrm{w} / \mathrm{v}$ in normal saline) into the sub-plantar tissue of the right hind paw. The linear paw circumference was measured using the digital screw gauze. Measurements were made immediately before injection of the phlogistic agent and at hourly inter- 
vals for $4 \mathrm{~h}$ in the animals injected with Carrageenan. Negative control group was given only Normal saline $10 \mathrm{ml} / \mathrm{kg}$ with no induction of inflammation and in all other group inflammation was induced by Carageenan injection. No any treatment was given to positive control group and in standard group Indomethacin $(10 \mathrm{mg} / \mathrm{kg}$ BW) was administered orally $1 \mathrm{hr}$ before injection of phlogistic agents. The extract dose was also administered orally $1 \mathrm{hr}$ before inflammation induction. ${ }^{13-16}$

\section{Statistical analysis}

The results obtained represents the mean \pm SEM, for number of animals used $(n)=6$. The result was statistically analyzed by one-way ANOVA followed by Tukey's multiple comparison tests. The $p$-value $<0.05$ was considered to be statistically significant, $\mathrm{p}$-value $<0.01$ was considered statistically more significant and $\mathrm{p}$-value $<0.001$ was considered to be statistically highly significant when compared with control.

\section{RESULTS}

\section{Acute Oral Toxicity study}

It was determined that the maximum safe dose of extract in rats is $2000 \mathrm{mg} / \mathrm{kg}$ by acute oral toxicity studies. The studies followed OECD guidelines 423. Based on observations, it was evident that there was no reduction in alertness, spontaneous motor activity, reactivity to sound and touch, body and limb tone. Respiration, urination, pupil size and pineal, corneal and righting reflexes were found normal for all 14 days of study. Abnormal signs pertaining to toxicity such as ataxia, body tremors, convulsions, lacrimation, salivation, diarrhoea, writhing, piloerection, sedation, coma, cyanosis etc. were not observed in all groups during experimental tenure of 14 days.

\section{Analgesic activity \\ Tail Flick method}

In study of analgesic activity by Tail Flick method, the methanol extract of Cordia obliqua Willd. leaf significantly increased the reaction time. The positive control group was compared with standard i.e. Indomethacin $(10 \mathrm{mg} / \mathrm{kg})$ and three different doses $(125 \mathrm{mg} / \mathrm{kg}, 250 \mathrm{mg} / \mathrm{kg}$ and 500 $\mathrm{mg} / \mathrm{kg})$ of methanol extract. In this activity only high dose $(500 \mathrm{mg} / \mathrm{kg})$ has been shown significant $(\mathrm{p}<0.05)$ effect after 90 min of treatment. The reference drug Indomethacin has also shown only significant $(\mathrm{p}<0.05)$ effect Table 1, Figure 1a.

Hot Plate method

In study of analgesic activity by Hot Plate method, the methanol extract of Cordia obliqua Willd. leaf significantly increased the reaction time. The positive control group was compared with standard i.e. Indomethacin $(10 \mathrm{mg} / \mathrm{kg})$ and three different doses $(125 \mathrm{mg} / \mathrm{kg}, 250 \mathrm{mg} / \mathrm{kg}$ and 500 $\mathrm{mg} / \mathrm{kg})$ of methanol extract. In this activity both doses $(250 \mathrm{mg} / \mathrm{kg}$ and $500 \mathrm{mg} / \mathrm{kg}$ ) has been shown highly significant $(\mathrm{p}<0.001)$ effect after $90 \mathrm{~min}$ of treatment. The reference drug Indomethacin has shown highly significant $(\mathrm{p}<0.001)$ effect Table 2, Figure $1 b$.

In the both methods, analgesic activity was confirmed for Cordia obliqua Willd. leaf methanol extract. The high dose is more effective as compared to low doses and analgesic effect is higher and comparable with standard drug after 1 h of drug administration.

\section{Antipyretic activity}

In study of antipyretic activity by Yeast induced pyrexia method, the methanol extract of Cordia obliqua Willd. leaf significantly decreased body temperature. The positive control group was compared with standard drug i.e. Paracetamol $(100 \mathrm{mg} / \mathrm{kg})$ and three different doses $(125 \mathrm{mg} / \mathrm{kg}$, $250 \mathrm{mg} / \mathrm{kg}$ and $500 \mathrm{mg} / \mathrm{kg}$ ) of methanol extract. In this activity study, all

Table 1: Effect of COME on Tail Flick reaction time in rats.

\begin{tabular}{ccccccc}
\hline & & \multicolumn{5}{c}{ Reaction time in sec at time in min. } \\
\hline Group & Dose & $0 \mathrm{~min}$ & $30 \mathrm{~min}$ & $60 \mathrm{~min}$ & $90 \mathrm{~min}$ & $120 \mathrm{~min}$ \\
\hline Control & $\ldots$. & $3.5 \pm 0.58$ & $3.75 \pm 0.50$ & $3.25 \pm 0.50$ & $3.5 \pm 0.58$ & $3.67 \pm 0.52$ \\
Standard (Indomethacin) & $10 \mathrm{mg} / \mathrm{kg}$ & $3.33 \pm 0.52$ & $4.17 \pm 0.41$ & $5.00 \pm 0.63$ & $5.67 \pm 0.52^{*}$ & $5.83 \pm 0.41^{*}$ \\
COME-1 & $125 \mathrm{mg} / \mathrm{kg}$ & $3.00 \pm 0.62$ & $3.50 \pm 0.55$ & $3.67 \pm 0.52$ & $4.16 \pm 0.41$ & $4.33 \pm 0.51$ \\
COME-2 & $250 \mathrm{mg} / \mathrm{kg}$ & $3.33 \pm 0.52$ & $3.83 \pm 0.41$ & $4.67 \pm 0.52$ & $4.67 \pm 0.52$ & $5.33 \pm 0.52$ \\
COME-3 & $500 \mathrm{mg} / \mathrm{kg}$ & $3.33 \pm 0.52$ & $4.16 \pm 0.75$ & $4.67 \pm 0.52$ & $5.50 \pm 0.52^{*}$ & $5.67 \pm 0.52^{*}$ \\
\hline
\end{tabular}

Each column represents the mean \pm SEM, number of animals used $(n)=6$

${ }^{*}(p<0.05),{ }^{* *}(p<0.01),{ }^{* *}(p<0.001)$ - compared with positive control, considered as significant, more significant, highly significant respectively.

One-way ANOVA followed by Tukey's multiple comparison test.

Table 2: Effect of COME on Hot Plate reaction time in rats.

\begin{tabular}{ccccccc}
\hline & \multicolumn{5}{c}{ Reaction time in sec at time in min. } \\
\hline Group & Dose & 0 min & $30 \mathrm{~min}$ & $60 \mathrm{~min}$ & $90 \mathrm{~min}$ & $120 \mathrm{~min}$ \\
\hline Control & $\ldots .$. & $8.25 \pm 0.95$ & $8.00 \pm 0.82$ & $8.25 \pm 0.5$ & $8.50 \pm 0.58$ & $8.75 \pm 0.5$ \\
Standard (Indomethacin) & $10 \mathrm{mg} / \mathrm{kg}$ & $8.75 \pm 0.5$ & $11.25 \pm 0.5^{* *}$ & $13.75 \pm 0.5^{* * *}$ & $15.50 \pm 0.58^{* * *}$ & $15.00 \pm 0.82^{* * *}$ \\
COME-1 & $125 \mathrm{mg} / \mathrm{kg}$ & $7.25 \pm 0.95$ & $8.25 \pm 0.5$ & $9.00 \pm 0.82$ & $9.75 \pm 0.50$ & $8.75 \pm 0.5$ \\
COME-2 & $250 \mathrm{mg} / \mathrm{kg}$ & $7.5 \pm 0.58$ & $9.0 \pm 0.82$ & $10.25 \pm 0.50$ & $12.75 \pm 0.50^{* * *}$ & $12.25 \pm 0.50^{* * *}$ \\
COME-3 & $500 \mathrm{mg} / \mathrm{kg}$ & $7.75 \pm 0.5$ & $10.25 \pm 0.5$ & $12.0 \pm 0.82^{* * *}$ & $14.75 \pm 0.5^{* * *}$ & $14.75 \pm 0.5^{* * *}$ \\
\hline
\end{tabular}

Each column represents the mean \pm SEM, number of animals used $(n)=6$

${ }^{*}(p<0.05),{ }^{* *}(p<0.01),{ }^{* *}(p<0.001)$ - compared with positive control, considered as significant, more significant, highly significant respectively.

One-way ANOVA followed by Tukey's multiple comparison test 


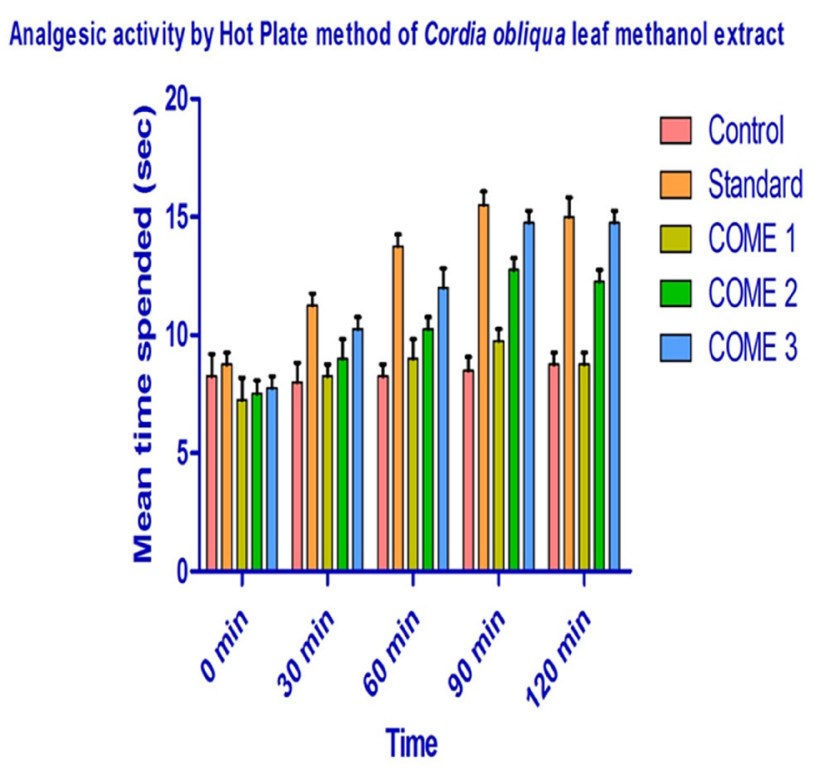

Analgesic activity by Tail Flick method of Cordia obliqua leaf methanol extract

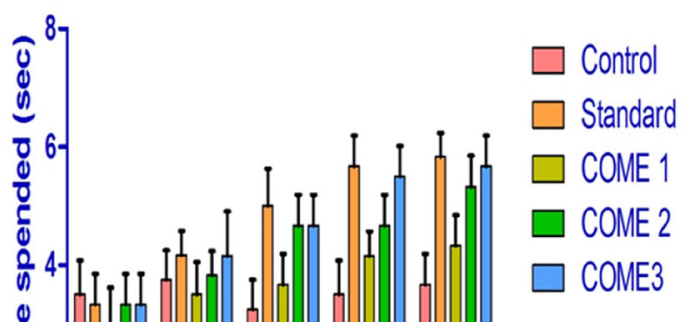

Figure 1: Analgesic effect shown by Cordia obliqua leaf methanol extract.

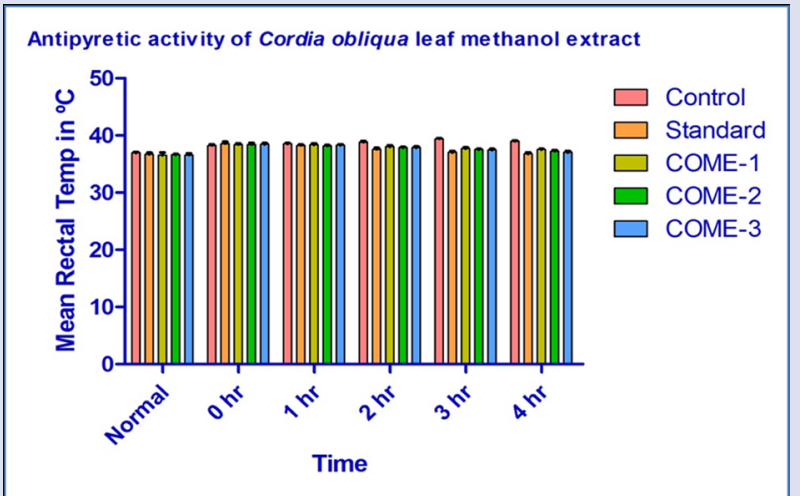

Figure 2: Antipyretic activity shown by Cordia obliqua leaf methanol extract.

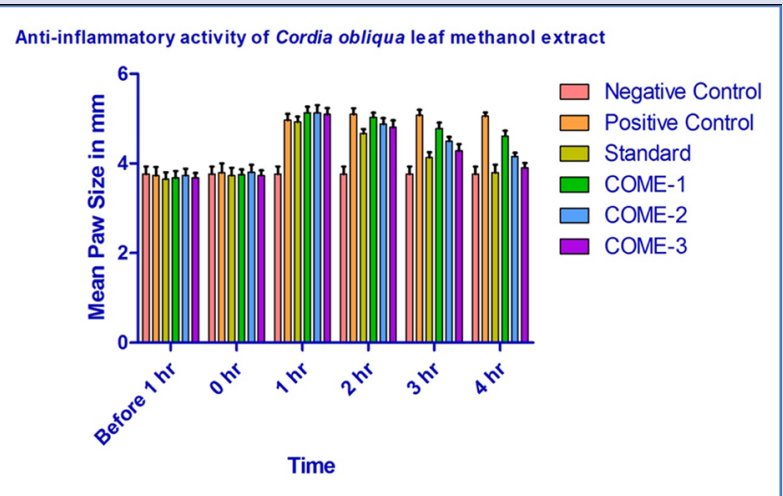

Figure 3: Anti-inflammatory activity shown by Cordia obliqua leaf methanol extract. doses of methanol extract have shown highly significant $(\mathrm{p}<0.001)$ effect after $3 \mathrm{~h}$ of drug administration. The reference drug Paracetamol has also shown highly significant $(\mathrm{p}<0.001)$ effect Table 3, Figure 2 .

\section{Anti-inflammatory activity}

In Carrageenan induced animal model, the methanol extract of Cordia obliqua Willd. leaf significantly inhibited the edema. The positive control group was compared with standard i.e. Indomethacin $(10 \mathrm{mg} / \mathrm{kg})$ and three different doses $(125 \mathrm{mg} / \mathrm{kg}, 250 \mathrm{mg} / \mathrm{kg}$ and $500 \mathrm{mg} / \mathrm{kg})$ of methanol extract. The dose $(250 \mathrm{mg} / \mathrm{kg})$ has been shown highly significant $(\mathrm{p}<0.001)$ effect after $4 \mathrm{~h}$ of drug administration and the dose $(500 \mathrm{mg} / \mathrm{kg})$ has also shown highly significant $(\mathrm{p}<0.001)$ effect after $3 \mathrm{~h}$ of drug administration. The low dose has shown no any significant effect. The reference drug Indomethacin has shown highly significant $(\mathrm{p}<0.001)$ effect Table 4 , Figure 3

\section{DISCUSSION}

The results of present study showed that Cordia obliqua leaf methanol extract (COME) maximum safe dose was $2000 \mathrm{mg} / \mathrm{kg}$ and it has good analgesic, antipyretic and anti-inflammatory activity when compared with suitable standard drug. The results support traditionally mentioned uses of this plant as well as pharmacological importance of genus Cordia according to previous studies. ${ }^{17,18}$

The two models of thermal nociception, hot plate and tail flick method were used to evaluate the central analgesic activity of COME. ${ }^{6}$ In hot plate method the two-dose level (medium and high) of COME showed highly significant analgesic effect after $90 \mathrm{~min}$ of administration. In tail 
Table 3: Effect of COME on Induction of yeast induces pyrexia in rats.

\begin{tabular}{cccccccc}
\hline \multirow{2}{*}{ Drug } & Dose & \multicolumn{5}{c}{ Rectal temperature in ${ }^{\circ} \mathrm{C}$ at time (hr) } \\
\cline { 3 - 7 } & & Normal & $0 \mathrm{hr}$ & $1 \mathrm{hr}$ & $2 \mathrm{hr}$ & $3 \mathrm{hr}$ \\
\hline Positive control (15\% brewer's yeast) & $1 \mathrm{ml} / 100 \mathrm{gm}$ & $36.92 \pm 0.17$ & $38.23 \pm 0.19$ & $38.51 \pm 0.13$ & $38.83 \pm 0.19$ & $39.038 \pm 0.12$ & $38.97 \pm 0.12$ \\
Standard (Paracetamol) & $10 \mathrm{mg} / \mathrm{kg}$ & $36.70 \pm 0.29$ & $38.55 \pm 0.33$ & $38.21 \pm 0.20$ & $37.55 \pm 0.27^{* * *}$ & $37.03 \pm 0.23^{* * *}$ & $36.75 \pm 0.27^{* * *}$ \\
COME-1 & $125 \mathrm{mg} / \mathrm{kg}$ & $36.51 \pm 0.17$ & $38.41 \pm 0.19$ & $38.37 \pm 0.25$ & $38.02 \pm 0.26$ & $37.70 \pm 0.20^{* * *}$ & $37.51 \pm 0.15^{* * *}$ \\
COME-2 & $250 \mathrm{mg} / \mathrm{kg}$ & $36.59 \pm 0.14$ & $38.41 \pm 0.27$ & $38.16 \pm 0.16$ & $37.85 \pm 0.14^{*}$ & $37.53 \pm 0.13^{* * *}$ & $37.23 \pm 0.21^{* * *}$ \\
COME-3 & $500 \mathrm{mg} / \mathrm{kg}$ & $36.55 \pm 0.31$ & $38.43 \pm 0.23$ & $38.26 \pm 0.19$ & $37.86 \pm 0.19^{*}$ & $37.43 \pm 0.22^{* * *}$ & $37.00 \pm 0.26^{* * *}$ \\
\hline
\end{tabular}

Each column represents the mean S.E.M.; number of animals used $(\mathrm{n}=6)$.

${ }^{*}(p<0.05),{ }^{* *}(p<0.01),{ }^{* *}(p<0.001)$ - compared with positive control, considered as significant, more significant, highly significant respectively.

One-way ANOVA followed by Tukey's multiple comparison Test

Table 4: Effect of COME on Carrageenan Induced Paw Edema in rats.

\begin{tabular}{|c|c|c|c|c|c|c|c|}
\hline \multirow{2}{*}{ Drug } & \multirow{2}{*}{ Dose } & \multicolumn{6}{|c|}{ Paw size in $\mathrm{mm}$ at time $(\mathrm{hr})$} \\
\hline & & Before $1 \mathrm{hr}$ & $0 \mathrm{hr}$ & $1 \mathrm{hr}$ & $2 \mathrm{hr}$ & $3 \mathrm{hr}$ & $4 \mathrm{hr}$ \\
\hline Negative Control & -- & $3.77 \pm 0.16$ & $3.77 \pm 0.16$ & $3.77 \pm 0.16$ & $3.77 \pm 0.16$ & $3.77 \pm 0.16$ & $3.77 \pm 0.16$ \\
\hline $\begin{array}{l}\text { Positive control } \\
\text { (carrageenan 1\%) }\end{array}$ & $0.1 \mathrm{ml}$ & $3.73 \pm 0.19$ & $3.8 \pm 0.2$ & $4.97 \pm 0.14$ & $5.1 \pm 0.13$ & $5.08 \pm 0.12$ & $5.06 \pm 0.08$ \\
\hline $\begin{array}{c}\text { Standard } \\
\text { (Indomethacin) }\end{array}$ & $10 \mathrm{mg} / \mathrm{kg}$ & $3.65 \pm 0.15$ & $3.73 \pm 0.17$ & $4.93 \pm 0.12$ & $4.67 \pm 0.10$ & $4.13 \pm 0.12^{* * *}$ & $3.8 \pm 0.17^{* * *}$ \\
\hline COME-1 & $125 \mathrm{mg} / \mathrm{kg}$ & $3.68 \pm 0.15$ & $3.75 \pm 0.12$ & $5.13 \pm 0.14$ & $5.03 \pm 0.10$ & $4.78 \pm 0.13$ & $4.61 \pm 0.12$ \\
\hline COME-2 & $250 \mathrm{mg} / \mathrm{kg}$ & $3.73 \pm 0.15$ & $3.81 \pm 0.16$ & $5.13 \pm 0.17$ & $4.88 \pm 0.13$ & $4.5 \pm 0.09^{*}$ & $4.16 \pm 0.08^{* * *}$ \\
\hline COME-3 & $500 \mathrm{mg} / \mathrm{kg}$ & $3.68 \pm 0.11$ & $3.73 \pm 0.12$ & $5.1 \pm 0.14$ & $4.81 \pm 0.15$ & $4.28 \pm 0.15^{* * *}$ & $3.9 \pm 0.11^{* * *}$ \\
\hline
\end{tabular}

Each column represents the mean S.E.M.; number of animals used $(n=6)$.

${ }^{*}(\mathrm{p}<0.05),{ }^{* *}(\mathrm{p}<0.01),{ }^{* *}(\mathrm{p}<0.001)$ - compared with positive control, considered as significant, more significant, highly significant respectively.

One-way ANOVA followed by Tukey’s multiple comparison Test

flick method, only significant analgesic effect was observed with high dose level of COME after 90 min of administration. So, the result of hot plate method was comparatively better than result of tail flick method.

In the antipyretic study, the injection of Brewer's yeast subcutaneously, induces pyrexia by increasing Prostaglandin synthesis. It is called pathogenic fever and it is an important test for evaluation of antipyretic activity of all type of drugs. ${ }^{19,20}$ The possible mechanism of antipyretic action of Paracetamol may be inhibition of prostaglandin synthesis. ${ }^{21}$ In this study, all dose levels of COME significantly attenuated rectal temperature of yeast induced febrile rat. So, it can be postulated that COME contains some active principles that inhibit the release of prostaglandins.

For anti-inflammatory study, carrageenan-induced paw edema is well established animal model. Edema formation in rat paw due to carrageenan injection is a biphasic event of $1-5 \mathrm{~h}$; the initial phase of 1-1.5h is predominately a non-phagocytic edema followed by a second phase of 2-5h with increased formation of edema that may remain up to $5 h^{22,23}$ The initial phase edema induction is due to the action of mediators such as serotonin, histamine and bradykinin on vascular permeability. ${ }^{24}$ The late phase edema is the result of over production of prostaglandins. ${ }^{25}$ In this study, the high dose $(500 \mathrm{mg} / \mathrm{Kg})$ of COME has been found significantly effective in late phase of edema induction (after $3 \mathrm{~h}$ of treatment). So, the possible mechanism of anti-inflammation action may be inhibition of prostaglandin synthesis. Further study may be carried out to find out the exact mechanism of action for analgesic, antipyretic and anti-inflammatory activity of COME.

\section{CONCLUSION}

In the conclusion, the methanolic extract of Cordia obliqua leaf, has been proved as a natural safe remedy for treatment of analgesia, pyrexia and inflammation. The result of this study supports the traditional use of this plant leaf as analgesic, antipyretic and anti-inflammatory drug. It is the first study related with biological activities of Cordia obliqua leaf. Further, the isolation of active phyto-constituents from plant will help in understanding the mechanism of action for tested activities and also identification of lead molecules of clinical utility.

\section{ACKNOWLEDGEMENT}

The authors are grateful to IK Gujral Punjab Technical University, Jalandhar and ASBASJSM College of Pharmacy, Bela (Ropar) for providing all necessary assistance to carry out this research work.

\section{CONFLICT OF INTEREST}

The authors have no conflict of interest.

\section{ABBREVIATION USED}

COME: Cordia obliqua methanol extract; C. obliqua: Cordia obliqua; BW: Body weight; SEM: Standard Error of Mean.

\section{REFERENCES}

1. Pierangeli G, Vital G, Rivera W. Antimicrobial activity and cytotoxicity of Chromolaena odorata (L.f.) King and Robinson and Uncaria perrottetii (A. Rich) 
Merr. extracts. J Med Plants Res. 2009;3(7):511-18.

2. Kirtikar KR, Basu BD. Indian Medicinal Plants. Shiva offset press, Dehradun 1998;3:1674-81.

3. Gupta R, Gupta GD. A review on plant Cordia obliqua Willd. (Clammy Cherry). Pharmacogn Rev. 2015;9(18):127-31.

4. Gupta R, Gupta GD. Pharmacognostic, phytochemical and antioxidant studies on Cordia obliqua Willd. leaf. Int J Pharm Sci Res. 2016;7(11):4668-76

5. OECD. Guidelines for testing of chemical, Guideline 423, Acute Oral ToxicityAcute Toxic Class Method, OECD, Paris 2001

6. Goyal M, Ghosh M, Nagori BP, Sasmal D. Analgesic and anti-inflammatory studies of cyclopeptide alkaloid fraction of leaves of Ziziyphus nummularia. Saudi J Biol Sci. 2013;20(4):365-71.

7. Parle M, Yadav M. Laboratory animal for screening analgesics. Int Res J Pharm. 2013;4(1):15-19

8. Vogel GH, Scholkens BA, Sandow J, Muller G, Vogel WF. Drug Discovery and Evaluation. Pharmacol Assays 2. 2002;696-72.

9. Mohammed GJ, Mohammed JA, Hameed IH. Anti-bacterial, antifungal activity and chemical analysis of Punica granatum (Pomegrannate peel) using GC-MS and FTIR spectroscopy. Int J Pharmacogn Phytochem Res. 2016;8(3):480-94.

10. Bhasker VH, Balakrishnan N. Analgesic, anti-inflammatory and antipyretic activities of Pergularia daemia and Carissa carandas. DARU 2009;17(3):168-74.

11. Yang J-M, Jiang H, Dai H-L, Wang Z-W, Jia G-Z, Meng X-C. Feeble Antipyretic, Analgesic and Anti-inflammatory Activities were Found with Regular Dose 4'-O- $\beta$-D-Glucosyl-5-O-Methylvisamminol, One of the Conventional Marker Compounds for Quality Evaluation of Radix saposhnikoviae. Pharmacogn Mag. 2017;13(49):168-74.

12. Nisar M, Khan I, Simee SU, Gilani AH, Obaidullah, Perveen H. Anticonvulsant, analgesic and antipyretic activities of Taxus wallichiana Zucc. J Ethnopharmacol 2008;116(3):490-94

13. Okpo SO, Fatokun F, Adeyemi OO. Analgesic and anti-inflammatory activity of Crinum glaucum aqueous extract. J. Ethnopharmacol. 2001;78(2):207-11.

14. Sireeratawong $S$, Itharat $A$, Lerdvuthisopon $N$, Piyabhan $P$, Khonsung $P$,
Boonraeng S, et al. Anti-inflammatory, analgesic and antipyretic activities of the ethanol extract of Piper interruptum Opiz. and Piper chaba Linn. ISRN Pharmacol. $2012 ; 480265$.

15. Gupta R, Kaur J. Evaluation of analgesic, antipyretic and anti-inflammatory activity on Cordia dichotoma G. Forst. Leaf. Pharmacogn Res. 2015;7(1):126-30.

16. Gupta S, Singh A. Antimicrobial, analgesic and anti-inflammatory activity reported on Tamarindus indica Linn root extract. Pharmacogn J. 2017:9(3):410-16

17. Thirupathi K, Kumar SS, Raju VS, Ravikumar B, Krishna DR, Mohan GK. A review of medicinal plants of the genus Cordia: their chemistry and pharmacological uses. J Nat Remedies. 2008;8(1):1-10.

18. Oza MJ, Kulkarni YA. Traditional uses, phytochemistry and pharmacology of the medicinal species of the genus Cordia (Boraginaceae). J Pharm Pharmacol. 2017;69(7):755-89.

19. Muhammad N, Muhammad S, Khan H. Antipyretic, analgesic and anti-inflammatory activity of Viola betonicifolia whole plant. BMC Complem Altern Med. 2012;12(1):59.

20. Moltz H. Fever: causes and consequences. Neurosci Biobehav Rev 1993;17(3):237-69

21. Rawlins MS, Karger AG. Mechanism of salicylate-induced antipyresis. Biomed Central, 1973;311-24.

22. Khan I, Nisar M, Ebad F, Nadeem S, Saeed M, Khan H. Anti-inflammatory activities of Sieboldogenin from Smilax china Linn.: Experimental and computational studies. J Ethnopharmacol. 2009;121(1):175-77.

23. Khan MA, Khan $\mathrm{H}$, Khan S, Mahmood T, Khan PM, Jabar A. Anti-inflammatory, analgesic and antipyretic activities of Physalis minima Linn. J Enz Inhib And Med Chem. 2009;24(3):632-37.

24. Maity TK, Manda, SC, Mukherjee PK, Saha K, Pal M, Saha B. Studies on antiinflammatory effect of Cassia tora leaf extract (fam. Leguminosae). Phytother Res. 1998;12(3):221-23.

25. Perez-Guerreo C, Herrera MD, Ortiz R, Alvarez de Sotomayor M, Fernandez MA. A pharmacological study of Cecropia obtusifolia Bertol aqueous extract. J Ethnopharmacol. 2001;76(3):279-84 .

\section{GRAPHICAL ABSTRACT}

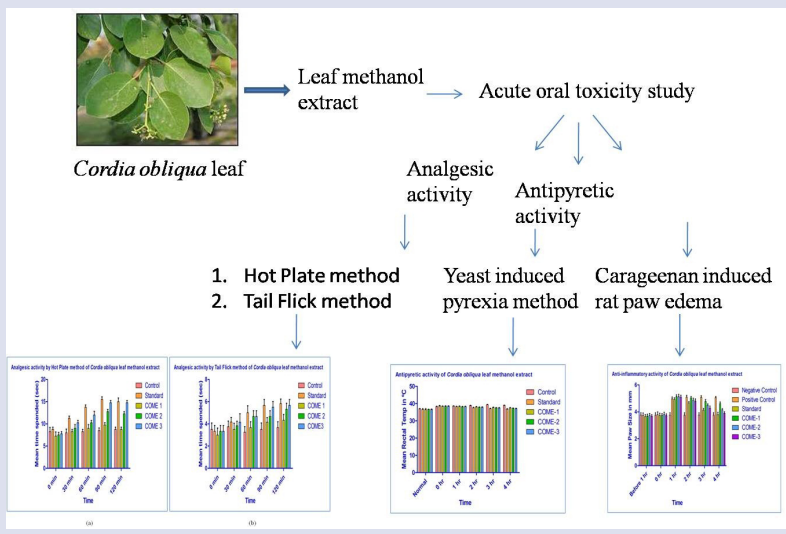

\section{SUMMARY}

- The methanol extract of Cordia obliqua leaf was selected for evaluation of analgesic, antipyretic and anti-inflammatory activities because it contains maximum amount of phytoconstituents.

- The extract dose up to $2000 \mathrm{mg} / \mathrm{kg}$ was found safe with no any toxic and side effects.

- For analgesic study two methods were used Hot plate and tail flick. For antipyretic study yeast induced pyrexia method and for anti-inflammatory study carageenan induced rat paw edema method was used.

- Three dose levels $(125 \mathrm{mg} / \mathrm{kg}, 250 \mathrm{mg} / \mathrm{kg}$ and $500 \mathrm{mg} / \mathrm{kg})$ of methanol extract were tested for all activities.

- The methanol extract was found effective in all activities as compared to standard drug. The effects were better with high dose level and the maximum activity was found against pyrexia.

\section{ABOUT AUTHORS}

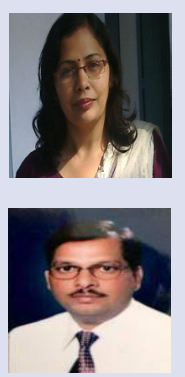

Richa Gupta: PhD scholar at IK Gujral Punjab Technical University and Assistant Professor at ASBASJSM College of Pharmacy, Bela, Ropar, Punjab. Work experience is 10 years.

Prof. (Dr.) Ghanshyam Das Gupta: Director IFS College of Pharmacy, Moga, Punjab. Work experience more than 20 years.

Cite this article: Gupta R, Gupta GD. Toxicity Assessment and Evaluation of Analgesic, Antipyretic and Anti-Inflammatory Activities on Cordia obliqua Leaf Methanol Extract. Pharmacog J. 2017;9(6):856-61. 